\title{
Effect of soil nitrogen supply on carbon assimilation by tree stems
}

\author{
Daniel BerveILleR ${ }^{1,2,3 *}$, Chantal FresneAU ${ }^{1,2,3}$ Claire DAMESIN $^{2,1,3}$ \\ ${ }^{1}$ CNRS, Laboratoire Ecologie Systématique et Evolution, UMR8079, 91405 Orsay, France \\ ${ }^{2}$ Univ Paris-Sud, 91405 Orsay, France \\ ${ }^{3}$ AgroParisTech, 75231 Paris, France
}

(Received 1 October 2009; accepted 19 January 2010)

Keywords:

stem photosynthesis /

nitrogen /

PEP carboxylase /

Rubisco /

Fagus sylvatica

\begin{abstract}
- Nitrogen $(\mathrm{N})$ is one of the most important resources for plants, generally enhancing leaf photosynthesis because a large part of it is allocated to Rubisco and thylakoïds. This is well known in leaves where photosynthesis (i.e. gas exchange, Rubisco activity, chlorophyll content) is positively correlated to leaf $\mathrm{N}$ content.

- In order to test this hypothesis in stems, $\mathrm{N}$ concentration, $\mathrm{CO}_{2}$ exchange and also Rubisco and PEP carboxylase activities were measured in summer on current-year stems of young European beeches (Fagus sylvatica $\mathrm{L}$.) growing on soils of different $\mathrm{N}$ content.

- The $\mathrm{CO}_{2}$ refixation rate of stems increased from $58.5 \%$ to $74.3 \%$ when stem $\mathrm{N}$ concentration increased from 5.7 to $10.1 \mathrm{mg} \mathrm{g}^{-1} \mathrm{DW}$. A hyperbolic relationship was obtained between stem gross photosynthesis and $\mathrm{N}$ concentration, with an $x$-intercept of $0.3 \mathrm{mmol} \mathrm{N} \mathrm{g}^{-1} \mathrm{DW}$. Stem PEP carboxylase activity was higher in stems than in leaves and increased with stem $\mathrm{N}$ concentration whereas Rubisco activity did not change between treatments in both tissues.

- In spite of a low nitrogen investment in stem photosynthesis (low PNUE), these results suggest that (1) stems invest more $\mathrm{N}$ in $\mathrm{CO}_{2}$ refixation when more $\mathrm{N}$ is widely available, (2) stem photosynthesis is able to operate at low $\mathrm{N}$ concentration and (3) stem PEP carboxylase is involved in stem carbon refixation, but also simultaneously supplies carbon skeletons for $\mathrm{N}$ assimilation.
\end{abstract}

\section{INTRODUCTION}

Along with carbon $(\mathrm{C})$, nitrogen $(\mathrm{N})$ is the most significant resource for plant functioning. In temperate ecosystems, soil nitrogen is a limiting element for plant growth because its concentration is kept low due to losses by leaching and microbial consumption (Tischner, 2000). N uptake occurs predominantly in roots by nitrate $\left(\mathrm{NO}_{3}^{-}\right)$and/or ammonium $\left(\mathrm{NH}_{4}^{+}\right)$absorption (Pate, 1973). In forest trees, $\mathrm{N}$ assimilation occurs mainly in roots while it occurs both in leaves and roots of herbaceous plants (Martin and Plassard, 1997). Whereas nitrates typically predominate in agricultural soils presenting high $\mathrm{N}$ turnover, neutral $\mathrm{pH}$ and good aeration, ammonium plays an important role in forest soils (Glass and Siddiqi, 1995). As is the case in herbaceous plants (Lee and Drew, 1989), nitrate uptake by roots of most tree species is strongly inhibited when ammonium is available (Gessler et al., 1998; Kreuzwieser et al., 1997; Rennenberg et al., 1996). However, in some species like ash and oak, ammonium has a positive effect on nitrate uptake (Stadler et al., 1993). In trees, ammonium uptake generally shows a seasonal course with maximum uptake rates occurring in mid-summer (Gessler et al., 1998). Nitrogen uptake during

* Corresponding author: daniel.berveiller@u-psud.fr bud break in spring is very low because the $\mathrm{N}$ demand can be almost completely satisfied by $\mathrm{N}$ remobilized from storage tissues (Millard, 1994; Millard and Proe, 1992). Later, during the fall, a large part of leaf $\mathrm{N}$ is stored in shoots as vegetative storage proteins (VSPs) that constitute the predominant proteins in dormant organs, especially in the woody compartment (Rowland and Arora, 1997; Stepien et al., 1994). In summer, bark apparently works as a transit area for nitrogen components, in particular, for the free amino acids synthesized in roots and carried in sap (Gomez and Faurobert, 2002).

The woody compartment is known to be an important source of C loss by respiration (Damesin et al., 2002; Granier et al., 2000), but stems are also able to assimilate C (Kharouk et al., 1995; Pearson and Lawrence, 1958; Pfanz et al., 2002; Pilarski, 1989; Wiebe, 1975). This photosynthesis process occurs particularly in the bark chlorenchyma and mainly consists in refixation of $\mathrm{C}$ released by respiration (Cernusak and Marshall, 2000; Damesin, 2003). Refixation of $\mathrm{CO}_{2}$ in young stems may compensate for $60-100 \%$ of the potential respiratory $\mathrm{C}$ loss and may sometimes exceed $\mathrm{CO}_{2}$ release (Berveiller et al., 2007a; Damesin, 2003; Wittmann et al., 2001). The other processes potentially involved in the $\mathrm{CO}_{2}$ release under illumination, i.e. photorespiration and mitochondrial respiration, 
do not play a major role in stem carbon exchange (Wittmann et al., 2006). Although of a lower magnitude than in leaves, some ecophysiological characteristics of stem photosynthesis are similar to those observed in leaves, such as the positive response of gas exchange to light and temperature (Wittmann and Pfanz, 2007; Wittmann et al., 2001), the positive response of electron transport rate to light (Manetas, 2004), and the presence of Rubisco (Berveiller and Damesin, 2008; Berveiller et al., 2007b; Schaedle and Brayman, 1986). Over a whole season, current-year stems of European beech (Fagus sylvatica) are able to assimilate the equivalent of $40 \%$ of the $\mathrm{C}$ lost by respiration (Damesin, 2003).

A large number of papers studying the interaction between C- and N-metabolisms in leaves are available. The pathways of the two elements depend on each other and both pathways are regulated by each other. The plant allocates $\mathrm{N}$ to tissue maintenance and protein turnover (Ryan, 1991) and to leaf photosynthesis, especially to Rubisco and thylakoïds. Strong correlations exist between $\mathrm{C}$ assimilation rate or Rubisco activity and leaf $\mathrm{N}$ concentration (Evans, 1989). Phosphoenolpyruvate (PEP) carboxylase is an important cross point between the two metabolisms as it is involved in supplying oxaloacetate to the Krebs cycle, thus ensuring a continuous replenishment of $\mathrm{C}_{4}$-dicarboxylic acid, which is necessary for nitrogen assimilation and amino acid biosynthesis (Huppe and Turpin, 1994). We have recently shown a very high activity of PEP carboxylase in young stems in comparison to leaves of adult European beeches (Berveiller and Damesin, 2008; Berveiller et al., 2007b). Stem photosynthesis is positively correlated to nitrogen concentration in an interspecific study (Berveiller et al., 2007a). Contrary to leaves, interactions between $\mathrm{C}$ - and N-metabolisms in woody stems are poorly documented, with the exception of the role of woody tissues as a $\mathrm{N}$ storage compartment during winter. In this context, we conducted an experiment on young European beeches planted in pots with three contrasted levels of $\mathrm{N}$ fertilization. Our goal was to determine if $\mathrm{N}$ had an impact on stem carbon functioning, especially on $\mathrm{CO}_{2}$ exchange and carboxylating enzymes.

\section{MATERIALS AND METHODS}

\subsection{Site description, plant materials and nitrogen supplies}

The study was conducted on the experimental field of the University of Paris-Sud $\left(48^{\circ} 42^{\prime} \mathrm{N}, 02^{\circ} 10^{\prime} \mathrm{E}\right), 25 \mathrm{~km}$ south-west of Paris, France. A set of nine four-year-old European beech trees (Fagus sylvatica L.) were planted outdoors in $90 \mathrm{~L}$ pots in December 2005. The soil substrate consisted of a mixture of $50 \%(\mathrm{v} / \mathrm{v})$ peat and $50 \%(\mathrm{v} / \mathrm{v})$ sand; its characteristics are detailed in Table I. It was a sandy soil, poor in nitrogen, with a high $\mathrm{C} / \mathrm{N}$ ratio and rather neutral-basic. All trees were watered every two weeks (depending on rainfall) in 2006 without any nitrogen supply.

In March 2007, i.e. one month before budburst, all trees were fertilized ("Opta Fond Plus" (BHS, Vemar, France) NPK 10-15-20 + $25 \% \mathrm{SO}_{3}+$ trace elements, $20 \mathrm{~g}$ per pot). At the same time, three trees received an additional supply $7.5 \mathrm{~g}$ fertilizer per pot ("Optacote 40N" (BHS, Vemar, France) NPK 40-0-0) and three other trees $20 \mathrm{~g}$
Table I. Characteristics of the soil substrate used when planting beech saplings, before any $\mathrm{N}$ fertilization. Measurements were achieved from soil aliquots from five pots for the texture and from soil aliquots from nine pots for each other characteristic. Data are means $\pm 1 \mathrm{SE}$.

\begin{tabular}{|c|c|c|}
\hline \multicolumn{2}{|c|}{ Soil substrate characteristics } & Mean values \\
\hline \multirow[t]{3}{*}{ Texture } & Clay $(<2 \mu \mathrm{m}) \mathrm{g} \mathrm{kg}^{-1}$ & $37.2 \pm 3.0$ \\
\hline & Silt $(2 / 50 \mu \mathrm{m}) \mathrm{g} \mathrm{kg}^{-1}$ & $15.6 \pm 2.04$ \\
\hline & Sand $(50 / 2000 \mu \mathrm{m}) \mathrm{g} \mathrm{kg}^{-1}$ & $947 \pm 4.5$ \\
\hline \multicolumn{2}{|c|}{ Organic carbon $(\mathrm{C}) \mathrm{g} \mathrm{kg}^{-1}$} & $40.1 \pm 3.44$ \\
\hline \multicolumn{2}{|c|}{ Total nitrogen $(\mathrm{N}) \mathrm{g} \mathrm{kg}^{-1}$} & $0.72 \pm 0.05$ \\
\hline \multicolumn{2}{|c|}{$\mathrm{C} / \mathrm{N}$ ratio } & $51.8 \pm 1.14$ \\
\hline \multicolumn{2}{|c|}{ Organic matter $\mathrm{g} \mathrm{kg}^{-1}$} & $64.1 \pm 3.80$ \\
\hline \multicolumn{2}{|c|}{$\mathrm{pH}$ in water } & $8.37 \pm 0.04$ \\
\hline \multicolumn{2}{|c|}{$\mathrm{pH}$ in KCL solution } & $7.95 \pm 0.04$ \\
\hline
\end{tabular}

per pot of "Optacote 40N". "Opta Fond Plus" and "Optacote 40N" consist of coated and compacted granules that slowly release nitrogen into the soil during six month. In this way, three treatments (with three trees per treatment) were achieved (expressed in grams of each element):

- Treatment T1: NPK 2-3-4,

- Treatment T2: NPK 5-3-4,

- Treatment T3: NPK 10-3-4.

All measurements detailed below were carried out on whole currentyear stems, as the chlorophyll cells likely to refixate $\mathrm{CO}_{2}$ are known to be present even up to the pith of current-year stems of Fagus sylvatica (Berveiller et al., 2007a).

\subsection{Gas-exchange measurements}

Gas-exchange measurements were performed in the laboratory with a LI-6400 portable photosynthesis system (LI-COR Biosciences, Lincoln, NE) equipped with the conifer chamber Model 6400-05. In mid-June 2007, three current-year stems of each tree were harvested. Detached stems were immediately recut under distilled water in the section of tissue produced the previous year and the current-year parts of stem were oriented in the chamber so that the top of the stems faced the light source $(2 \times 1000 \mathrm{~W}$ HQI, Osram, Munich, Germany). Measurements were made at $20{ }^{\circ} \mathrm{C}$, with a $\mathrm{CO}_{2}$ concentration of $390 \mu \mathrm{mol} \mathrm{mol}{ }^{-1}, 60 \%$ relative humidity and 1400 or $0 \mu \mathrm{mol} \mathrm{m} \mathrm{m}^{-2} \mathrm{~s}^{-1}$ of photosynthetically active radiation (PAR) to determine $\mathrm{CO}_{2}$ efflux rates in the light $\left(R_{\mathrm{l}}\right)$ and in the dark, i.e., dark respiration rate $\left(R_{\mathrm{d}}\right)$ (for further details of method used for gas exchange see Berveiller et al., 2007a). Assuming that a light-induced inhibition of respiration is unlikely to occur (Wittmann et al., 2006), stem gross photosynthesis $\left(P_{\mathrm{g}}\right)$ may be calculated as:

$$
P_{\mathrm{g}}=\left|R_{\mathrm{d}}-R_{\mathrm{l}}\right| \text {. }
$$

From gas exchange measurements, the refixation rate was calculated as follows:

$$
\text { Refixation rate }(\%)=\frac{R_{\mathrm{d}}-R_{\mathrm{l}}}{R_{\mathrm{d}}} \times 100 \text {. }
$$

After gas-exchange measurements, total surface areas of stems (not projected surface areas) were measured to express $\mathrm{CO}_{2}$ efflux in terms of area units. Stem tissues were then dried at $60{ }^{\circ} \mathrm{C}$ for $48 \mathrm{~h}$, weighed and ground for nitrogen concentration measurements (see Sect. 2.3). 
Table II. Mass-based N concentrations ( $\mathrm{mg} \mathrm{g}^{-1} \mathrm{DW}$ ) and leaf or stem mass per area (LMA and SMA, $\mathrm{g}$ DW $\mathrm{m}^{-2}$ ) of leaves and current-year stems of Fagus sylvatica L. in each N treatment (T1, T2, and T3). Data are means \pm 1 SE with $n=3$. For each organ (leaves or stems), letters $(a, b$, and $c)$ indicate significant differences between $\mathrm{N}$ treatments.

\begin{tabular}{ccccc}
\hline \multirow{2}{*}{ N treatment Leaves } & \multicolumn{2}{c}{ Current-year stems } \\
\cline { 2 - 5 } & N concentration & LMA & N concentration & SMA \\
\hline T1 & $10.2 \pm 0.13 a$ & $67.4 \pm 0.76 a$ & $5.67 \pm 0.20 a$ & $276.7 \pm 7.90 a$ \\
T2 & $17.2 \pm 0.79 b$ & $72.1 \pm 3.74 a$ & $10.1 \pm 1.05 b$ & $307.9 \pm 34.5 a$ \\
T3 & $14.1 \pm 1.27 c$ & $70.9 \pm 3.07 a$ & $8.00 \pm 0.81 a b$ & $294.7 \pm 8.53 a$ \\
\hline
\end{tabular}

\subsection{Nitrogen concentration}

At the end of June 2007, three leaves and three current-year stems of each tree were sampled and dried at $60{ }^{\circ} \mathrm{C}$ for $48 \mathrm{~h}$. Dry mass (DW) of each sample (sampled in mid-June for gas exchange measurement, see above, and at the end of June) was determined. The samples were then cut into small pieces and ground to a powder (MM200, RETSCH, Haan, Germany). The nitrogen concentration of the powder was determined with an elemental analyzer at the "Service Central d'Analyse du CNRS" (Vernaison, France).

\subsection{Protein extraction}

Frozen materials $(500 \mathrm{mg})$ of leaves and whole stem segments were weighed rapidly, powdered with a pestle in a pre-chilled mortar under liquid $\mathrm{N}_{2}$ and ground in an extraction buffer containing 100 mM HEPES (pH 8), $10 \mathrm{mM} \mathrm{MgCl} 2,7 \%$ (w/w) polyethylene glycol $20000,10 \mathrm{mM}$ dithiothreitol, $10 \%$ (v/v) glycerol, three antiproteases (20 $\mu \mathrm{M} 4$-amidinophenylmethanesulfonyl fluoride ( $p$-APMSF), $1 \mu \mathrm{M}$ pepstatin, $1 \mu \mathrm{M}$ leupeptin) and an antiphosphatase cocktail (Sigma). During grinding, polyvinylpolypyrrolidone (PVPP) was added. The homogenates were centrifuged for $25 \mathrm{~min}$ at $4{ }^{\circ} \mathrm{C}$ in a microcentrifuge (5 $804 \mathrm{R}$; EPPENDORF, Germany) at $15000 \mathrm{~g}$. An aliquot of the supernatant was used for protein determination. The remainder was passed through a desalting column (Sephadex G25 ${ }^{\mathrm{TM}}$ Pharmacia; AMERSHAM, Sweden) for enzyme assays.

\subsection{Enzyme assays}

According to Berveiller et al. (2007b), PEP carboxylase activity was measured at $\mathrm{pH} 7.8$ in a buffer containing $100 \mathrm{mM}$ HEPES, $10 \mathrm{mM} \mathrm{MgCl}_{2}, 5 \mathrm{mM} \mathrm{NaHCO}, 0.2 \mathrm{mM} \mathrm{NADH}$, and $3 \mathrm{U} \mathrm{mL}^{-1}$ malate dehydrogenase. This assay was initiated by the addition of $5 \mathrm{mM}$ phosphoenolpyruvate (Tietz and Wild, 1991; Uedan and Sugiyama, 1976).

Rubisco initial and total activities were measured in a buffer containing $100 \mathrm{mM}$ HEPES ( $\mathrm{pH}$ 8) , $20 \mathrm{mM} \mathrm{MgCl}_{2}, 25 \mathrm{mM}$ $\mathrm{NaHCO}_{3}, 3.5 \mathrm{mM}$ ATP, $0.2 \mathrm{mM}$ NADH, $5 \mathrm{mM}$ creatine phosphate, $5 \mathrm{U} \mathrm{mL}^{-1}$ glyceraldehyde-3-phosphate dehydrogenase, $5 \mathrm{U} \mathrm{mL}^{-1} 3$ phosphoglycerokinase, $5 \mathrm{U} \mathrm{mL}^{-1}$ creatine phosphokinase. The assays were initiated by addition of $0.5 \mathrm{mM}$ ribulose-1,5-bisphosphate for the Rubisco initial activity and after $15 \mathrm{~min}$ incubation of the extract at $30{ }^{\circ} \mathrm{C}$ for the Rubisco total activity.

PEP carboxylase and Rubisco activities were determined by UV spectrometry following NADH oxidation at $340 \mathrm{~nm}$. Activities were expressed in $\mu \mathrm{mol} \mathrm{CO}_{2}$ or $\mathrm{HCO}_{3}^{-}$consumed per min and per mg proteins for Rubisco and PEP carboxylase respectively. Soluble protein concentrations were determined by the Bradford assay (BioRad, Hercules, CA, USA) using bovine serum albumin as a standard (Bradford, 1976).

\subsection{Statistical analysis}

Statistical analyses were performed with Statistica (Statsoft Inc., Tulsa, OK). The statistical significance of N concentration, gas exchange, and enzyme activities between the three nitrogen treatments was calculated with analysis of variance (ANOVA). Treatment effects were considered significant if $P<0.05$ (Fisher's LSD test). A nonlinear relationship was fitted between gross photosynthetic rate and nitrogen concentration using the following relationship:

$$
P_{\mathrm{g}}=\frac{a \times(N-b)}{c+(N-b)}
$$

where $P_{\mathrm{g}}$ is the gross photosynthetic rate, $N$ is the total nitrogen concentration, and $a, b$, and $c$, the three parameters obtained by ordinary least-squares estimation.

\section{RESULTS}

\subsection{Effect of $\mathbf{N}$ treatment on the $\mathbf{N}$ status of above-ground parts}

In treatment $\mathrm{T} 1$, beech trees accumulated nitrogen in aboveground parts with values reaching $10.2 \mathrm{mg} \mathrm{g}^{-1}$ dry weight (DW) in leaves and $5.67 \mathrm{mg} \mathrm{g}^{-1} \mathrm{DW}$ in current-year stems (Tab. II). Additional supplies of nitrogen in soil (in treatments $\mathrm{T} 2$ and $\mathrm{T} 3$ ) resulted in a significant increase of nitrogen concentration in the leaves and current-year stems, expressed either in mass-based or area-based units (for stems). The nitrogen concentration reached 17.2 and $10.1 \mathrm{mg} \mathrm{g}^{-1} \mathrm{DW}$ in treatment $\mathrm{T} 2$ and 14.1 and $8.00 \mathrm{mg} \mathrm{g}^{-1} \mathrm{DW}$ in treatment $\mathrm{T} 3$, for leaves and current-year stems, respectively. No significant differences were observed between treatments T2 and T3 either for leaves or for current-year stems.

\subsection{Effect of $\mathbf{N}$ treatment on the gas exchange of current-year stems}

Whatever the treatment, we observed a reduction of stem $\mathrm{CO}_{2}$ efflux upon illumination, i.e. $60 \%, 74 \%$, and $68 \%$ in treatments T1, T2 and T3, respectively (Fig. 1). Upon illumination, $R_{l}$ ranged from $-0.71 \mu \mathrm{mol} \mathrm{CO}_{2} \mathrm{~m}^{-2} \mathrm{~s}^{-1}$ (treatment $\mathrm{T} 1$ ) 


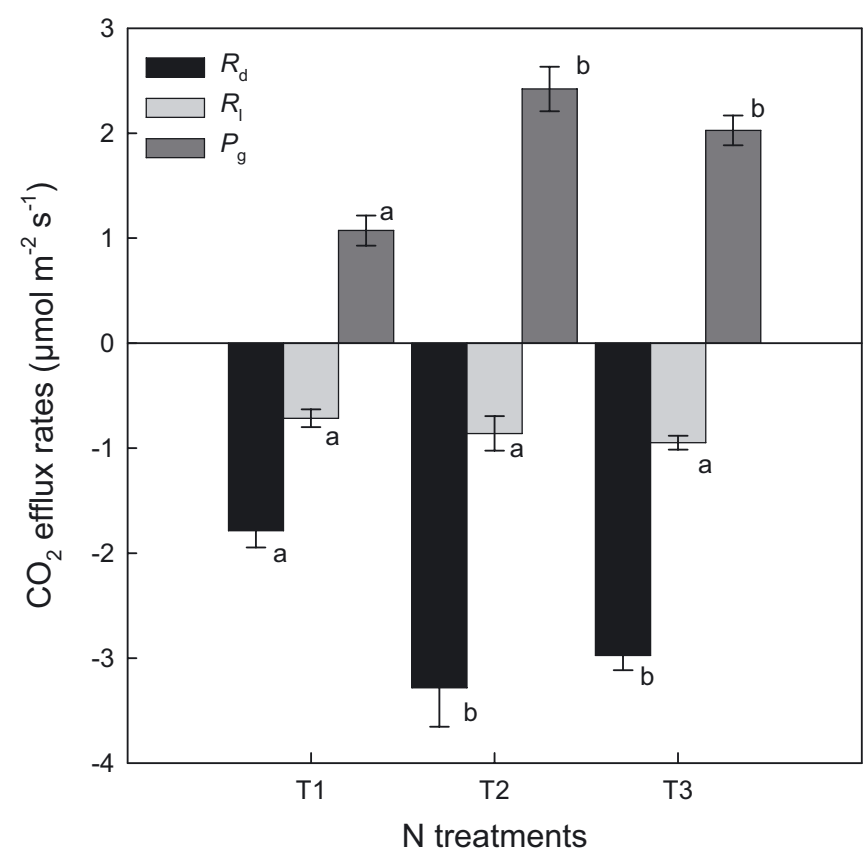

Figure 1. Gas exchange of current-year stems of Fagus sylvatica L. measured as $\mathrm{CO}_{2}$ efflux in the dark (dark respiration rate, $R_{\mathrm{d}}$ ), $\mathrm{CO}_{2}$ efflux under saturated light $\left(R_{\mathrm{l}}\right)$ and calculated rates of gross photosynthesis $\left(P_{\mathrm{g}}\right)$, for each $\mathrm{N}$ treatment (T1, T2, and T3). Data are means $\pm 1 \mathrm{SE}$, with $n=3$. Letters $(a, b$, and $c)$ indicate significant differences between $\mathrm{N}$ treatments, for each parameter $\left(R_{\mathrm{d}}, R_{\mathrm{l}}\right.$ and $\left.P_{\mathrm{g}}\right)$.

to $-0.95 \mu \mathrm{mol} \mathrm{CO} \mathrm{CO}_{2} \mathrm{~m}^{-2} \mathrm{~s}^{-1}$ (treatment $\mathrm{T} 3$ ) and no significant difference was observed between treatments. In the treatment T1, dark respiration rate $\left(R_{\mathrm{d}}\right)$ and gross photosynthesis rate $\left(P_{\mathrm{g}}\right)$ were equal to 1.79 and $1.07 \mu \mathrm{mol} \mathrm{m} \mathrm{m}^{-2} \mathrm{~s}^{-1}$, respectively. The additional supply of nitrogen (treatments T2 and T3) resulted in a significant increase of gas exchange intensity. $R_{\mathrm{d}}$ increased rates by $83 \%$ and $66 \%$ between treatments $\mathrm{T} 1$ and $\mathrm{T} 2$ and between $\mathrm{T} 1$ and $\mathrm{T} 3$, respectively; $P_{\mathrm{g}}$ increased rates by $126 \%$ and $90 \%$ between treatments $\mathrm{T} 1$ and $\mathrm{T} 2$ and between $\mathrm{T} 1$ and $\mathrm{T} 3$, respectively.

\subsection{Relationships between gross photosynthesis rate, respiration rate and $\mathbf{N}$ concentration in current- year stems}

Pooling data from all treatments (expressed in area-based units), the linear relationship observed between gross photosynthesis rate and dark respiration rate was significant $\left(r^{2}=0.88 ; P<0.0001\right.$, Fig. 2). Carbon refixation by stem photosynthesis represented $80 \%$ of the total respiration rate. Expressed in mass-based units, the relationship was also significant with $r^{2}=0.84(P<0.0001$, data not shown $)$. Considering each treatment separately, the following refixation rates were obtained: $58.5 \% \pm 4.66$ for $\mathrm{T} 1,74.3 \% \pm 1.85$ for $\mathrm{T} 2$ and $68.2 \pm 2.17$ for $\mathrm{T} 3$.

Gross photosynthesis rates were highly related with the nitrogen concentrations values in current-year stems of $\mathrm{Eu}-$

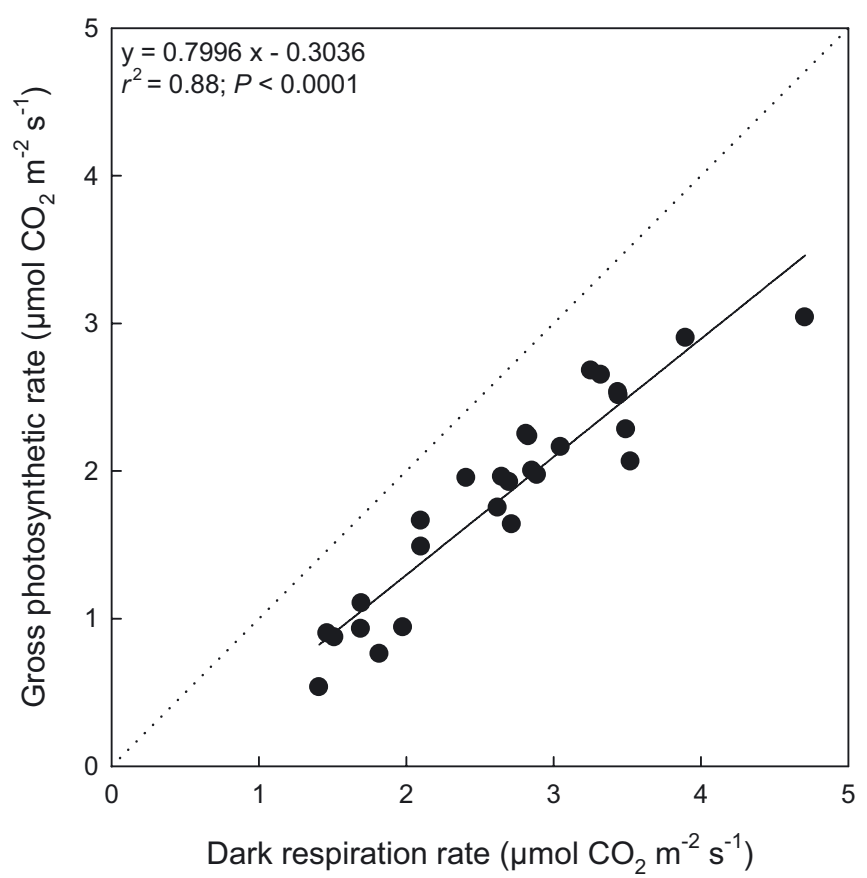

Figure 2. Relationship between area-based gross photosynthesis $\left(P_{\mathrm{g}}\right)$ and area-based dark respiration rate $\left(R_{\mathrm{d}}\right)$ of current-year stems of $\mathrm{Fa}$ gus sylvatica L. trees subjected to different nitrogen treatments. Each value corresponds to one of the three current-year stems sampled on each of the nine trees (three per $\mathrm{N}$ treatment).

ropean beech $\left(r^{2}=0.83 ; P<0.0001\right.$, Fig. 3$)$. The response of gross photosynthesis to nitrogen increase followed a hyperbolic-type model. From this non-linear model, the maximum gross photosynthetic rate for saturating nitrogen concentration was calculated as $9.73 \mu \mathrm{mol} \mathrm{CO} \mathrm{kg}^{-1} \mathrm{DW} \mathrm{s}{ }^{-1}$. By extrapolating, the mass-based hyperbole crossed the $\mathrm{x}$-axis at $4.4 \mathrm{mg} \mathrm{N} \mathrm{g}^{-1} \mathrm{DW}\left(0.3 \mathrm{mmol} \mathrm{N} \mathrm{g}{ }^{-1} \mathrm{DW}\right)$.

\subsection{Effect of $\mathbf{N}$ concentration on soluble protein content and enzyme activities}

The total soluble protein content increased with increasing tissue $\mathrm{N}$ concentration (Fig. 4). The amount of protein ranged from $6.0 \mathrm{mg} \mathrm{g}^{-1}$ DW for treatment $\mathrm{T} 1$ to $10 \mathrm{mg} \mathrm{g}^{-1} \mathrm{DW}$ for treatment $\mathrm{T} 2$ for stems and from $19 \mathrm{mg} \mathrm{g}^{-1} \mathrm{DW}$ in treatment $\mathrm{T} 1$ to $34 \mathrm{mg} \mathrm{g}^{-1} \mathrm{DW}$ in treatment $\mathrm{T} 2$ for leaves.

Whatever the stem $\mathrm{N}$ concentration, Rubisco total activity was always higher in leaves than in current-year stems (by a factor of about 10-12 times, Fig. 5a). In average, activity in leaves ranged from 10.2 to $11 \mu \mathrm{mol} \mathrm{CO} \mathrm{min}^{-1} \mathrm{mg}^{-1}$ prot and from 0.85 to $0.91 \mu \mathrm{mol} \mathrm{CO} \mathrm{min}^{-1} \mathrm{mg}^{-1}$ prot in current-year stems. No significant effect of stem $\mathrm{N}$ concentration was observed on Rubisco activities, either in leaves or in current-year stems.

PEP carboxylase activity was from 1.9 to 3.4 times higher in current-year stems than in leaves (Fig. 5b). The PEP carboxylase activity in leaves ranged from 


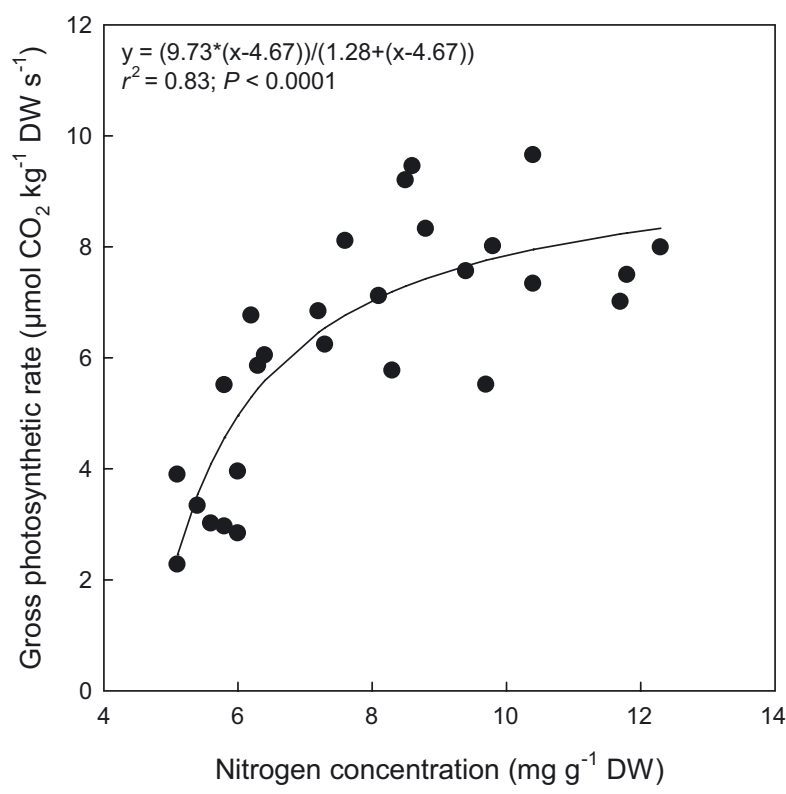

Figure 3. Relationship between mass-based gross photosynthesis $\left(P_{\mathrm{g}}\right)$ and mass-based nitrogen concentration of current-year stems of Fagus sylvatica L. trees subjected to different nitrogen treatment. Each value corresponds to one of the three current-year stems sampled on each of nine trees (three per treatment).

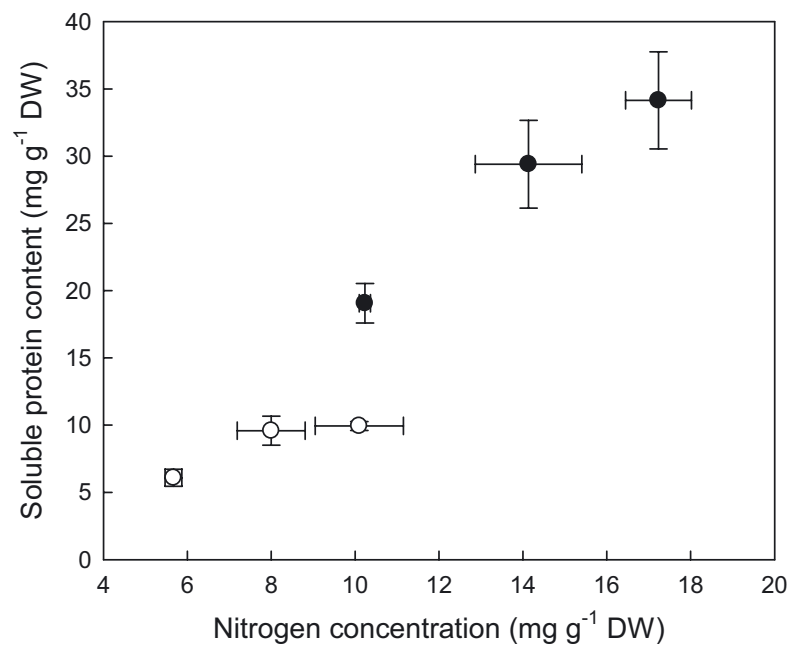

Figure 4. Relationship between mass-based total soluble protein content and mass-based nitrogen concentration of leaves (black-filled circles) and current-year stems (open circles) of Fagus sylvatica L. Each point corresponds to the mean value of each $\mathrm{N}$ treatment and mean value of protein content ( $n=3$ for each ones). The standard errors of the ordinate and abscissa values are shown as vertical and horizontal bars, respectively.

$1.4 \mu \mathrm{mol} \mathrm{min} \mathrm{mg}^{-1} \mathrm{mg}^{-1}$ prot in treatment $\mathrm{T} 3$ to $1.8 \mu \mathrm{mol} \mathrm{min} \mathrm{m}^{-1}$ $\mathrm{mg}^{-1}$ prot in treatment T2. In current-year stems, PEP carboxylase activity significantly increased with $\mathrm{N}$ concentration, ranging from $3.4 \mu \mathrm{mol} \mathrm{min}{ }^{-1} \mathrm{mg}^{-1}$ prot at $5.67 \mathrm{mg} \mathrm{N} \mathrm{g}^{-1} \mathrm{DW}$

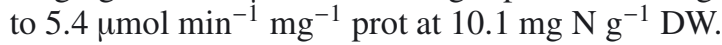

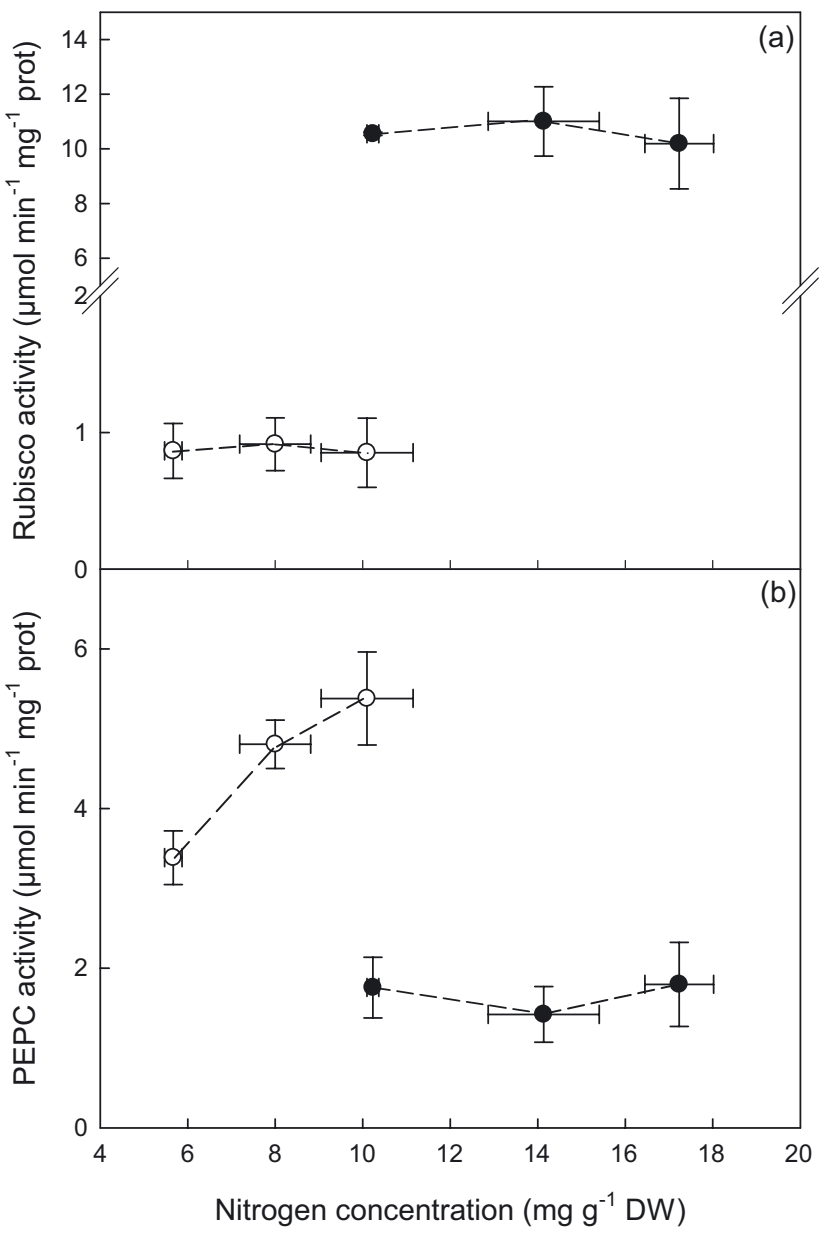

Figure 5. Relationships between Rubisco total activity and massbased nitrogen concentration (a) and between PEP carboxylase total activity and mass-based nitrogen concentration (b) of leaves (blackfilled circles) and current-year stems (open circles) of Fagus sylvatica $\mathrm{L}$. Each point corresponds to the mean value of a $\mathrm{N}$ treatment and mean value of enzyme activity ( $n=3$ for each ones). The standard errors of the ordinate and abscissa values are shown as vertical and horizontal bars, respectively.

\section{DISCUSSION}

Carbon $(\mathrm{C})$ and nitrogen $(\mathrm{N})$ management in perennial species like European beech is complex because of the use and remobilization of $\mathrm{N}$ reserves, especially during bud-burst period or fall, and in case of stress (Millard, 1994). It is generally difficult to obtain a large and significant effect of a soil $\mathrm{N}$ treatment on the metabolism and growth of trees. In our study, all trees were initially planted in a sandy soil having a low $\mathrm{N}$ content, without fertilizer addition throughout 2006. This certainly resulted in a decrease of $\mathrm{C}$ - and $\mathrm{N}$ - reserves of trees before the 2007 experiment. Although $\mathrm{N}$ treatments did not affect the structure of leaves or stems (no significant difference in leaf mass per area or stem mass per area with treatments), we observed a positive effect of $\mathrm{N}$ supply on the $\mathrm{N}$ status of trees with a significant increase in total $\mathrm{N}$ concentrations in both 
leaves and current-year stems (Tab. II). The N concentrations measured in leaves and stems for the treatment T2 were similar to values commonly observed on current-year stems of adult trees at the beginning of summer, i.e. $20 \mathrm{mg} \mathrm{g}^{-1} \mathrm{DW}$ and $10 \mathrm{mg} \mathrm{g}^{-1} \mathrm{DW}$ for leaves and current year stems, respectively (Berveiller et al., 2007a; Damesin, 2003). In both stems and leaves, the $\mathrm{N}$ concentrations similarly increased between treatments $\mathrm{T} 1$ and $\mathrm{T} 2(\times 1.7)$ or between $\mathrm{T} 1$ and $\mathrm{T} 3(\times 1.4)$. The amount of $\mathrm{N}$ supplied by treatment $\mathrm{T} 3$ seemed to be excessive because $\mathrm{N}$ accumulation in leaves and stems was lower for trees of the treatment $\mathrm{T} 3$ than for trees of the treatment $\mathrm{T} 2$. The $\mathrm{N}$ source of the fertilizer that we used is mainly composed of urea that releases ammonium $\left(\mathrm{NH}_{4}^{+}\right)$through urease enzyme activity. Because $\mathrm{NH}_{4}^{+}$absorption by roots uses an $\mathrm{NH}_{4}^{+} / \mathrm{H}^{+}$antiport channel, soil $\mathrm{pH}$ decreases when the soil is watered only with ammonium solution (Volk et al., 1992). As a result, a high fertilization level (case of the treatment T3) probably resulted in a decrease in $\mathrm{pH}$, thus limiting the $\mathrm{N}$ uptake by plant roots and $\mathrm{N}$ accumulation in leaves and current-year stems.

The reduction of stem $\mathrm{CO}_{2}$ efflux when a stem is transferred from dark to light is now well known and is mainly due to C assimilation by stem photosynthesis (Pfanz et al., 2002). Stem photosynthesis allows young stems of Fagus sylvatica to compensate for $60-100 \%$ of their $\mathrm{CO}_{2}$ loss by respiration, which corresponds to the refixation rate (Berveiller et al., 2007a; Damesin, 2003; Wittmann et al., 2001). Considering data from all $\mathrm{N}$ treatments of this study, similar results were found with a linear relationship between gross photosynthesis rate and dark respiration rate. This suggests that, like in leaves, products of stem photosynthesis are partially and directly used as substrates for respiration to sustain protein turn-over (McCree, 1969). An alternative explanation comes from the results obtained by Cernusak and Marshall (2000) who showed (1) a strong relationship between stem internal $\mathrm{CO}_{2}$ concentration measured in the dark and gross photosynthesis measured at saturated photon flux density in PAR $\left(P_{\mathrm{g}}\right)$ on young stems of Western White Pines, but (2) no significant correlation between stem internal $\mathrm{CO}_{2}$ concentration measured in the light and $P_{\mathrm{g}}$. These authors suggested that stems allocate their photosynthetic capacity to refixation depending on the dark respiration rates which lead to an efficient use of $\mathrm{N}$ for recycling respired $\mathrm{CO}_{2}$. This hypothesis is supported by our measurements which show that gross photosynthesis increases with increasing $\mathrm{N}$ concentration of the whole current-year stem. The relationship between light-saturated photosynthetic rate and $\mathrm{N}$ concentration is widely documented for leaves (Evans, 1989; Field and Mooney, 1986). This relationship exists between stems of various tree species (Berveiller et al., 2007a; 2007b) and this study shows that it is valid at an intraspecific level. This relationship is generally linear, but in our study, the mass-based and area-based relationships were found to be hyperbolic. By calculating the photosynthetic nitrogen use efficiency (PNUE, calculated as $\mathrm{C}$ assimilation rate to $\mathrm{N}$ concentration ratio) on a projected area basis, we showed that it increased from 18.8 to 22.7 and $24.4 \mu \mathrm{mol} \mathrm{CO} \mathrm{mol}^{-1} \mathrm{~N} \mathrm{~s}^{-1}$, in treatments T1, T2 and T3 respectively. These PNUE values are close to previous measurements performed on currentyear stems of adult trees (Berveiller et al., 2007a) and fairly similar to values commonly observed in conifer needles (e.g. Gower et al., 1993) but much lower than in broad-leaved trees (Poorter and Evans, 1998). A low $\mathrm{N}$ investment in stem photosynthesis and conifer needle could be the consequence of the long lifespan of these tissues that invest more $\mathrm{N}$ in compounds required for longevity and defense (Field and Mooney, 1986; Hikosaka et al., 1998).

The photosynthetic capacity is generally related to $\mathrm{N}$ concentration primarily because the proteins of the Calvin cycle and thylakoïds represent the majority of leaf nitrogen (Evans, 1989). Rubisco is the major carboxylating enzyme in leaves and its activity is highly correlated to leaf $\mathrm{N}$ concentration (Sage et al., 1987). Whereas soluble protein content in beech leaves and stems doubled in response to the rise in tissue $\mathrm{N}$ concentration (Fig. 4), the $\mathrm{N}$ treatment had no significant effect on Rubisco either in stems or leaves (Fig. 5a). The rise in soluble protein content might at least partly explain the relationship observed between respiration and nitrogen concentration (data not shown). It has been reported that allocation of $\mathrm{N}$ to Rubisco increases in leaves of herbaceous species with increasing soil N availability (Evans, 1989; Makino et al., 1994), but not in trees (Bauer et al., 2001; Ripullone et al., 2003). The activation level of Rubisco being very similar in stems and leaves (69\% and $71 \%$ respectively, data not shown), it could be calculated that Rubisco activities mirrored the concentrations of Rubisco in both tissues. As a result, Rubisco concentrations were twenty times lower in stems than in leaves and did not change with nitrogen availability. Thus, $\mathrm{N}$ seems to be allocated to other proteins than Rubisco in stems compared to leaves, without invalidating the positive impact of $\mathrm{N}$ availability on stem respiration that is directly associated to protein synthesis and protein turnover (Ryan, 1991). A likely stem $\mathrm{N}$ sink candidate is PEP carboxylase. As shown in previous studies (Berveiller and Damesin, 2008; Berveiller et al., 2007a; 2007b), PEP carboxylase activity was higher in stems than in leaves, suggesting that this enzyme is involved in stem photosynthesis (Fig. 5b). Whereas no significant differences were observed in leaf PEP carboxylase activities among nitrogen treatments, the PEP carboxylase activity increased up to $\times$ 1.6 in stems depending on tissue $\mathrm{N}$ concentration. This observation is comparable to the positive relationship observed between stem gross photosynthesis and N concentration (Fig. 3). Leaf and root PEP carboxylase is known to be stimulated by nitrogen supply because the enzyme is involved in supplying carbon skeletons to the Krebs cycle (anaplerotic carbon fixation), thus ensuring a continuous replenishment of $\mathrm{C}_{4}$-dicarboxylic acid, which is necessary for nitrogen assimilation and amino acid biosynthesis (Huppe and Turpin, 1994). Our previous work showed that the stem PEP carboxylase is similar to the leaf PEP carboxylase of Fagus sylvatica, particularly regarding the biochemical characteristics of the enzyme (Berveiller et al., 2007b). In leaves, PEP carboxylase is activated under illumination, following its phosphorylation by a light-sensitive PEP carboxylase kinase (see e.g. Li et al., 1996). To confirm the important role of the enzyme in stem carbon assimilation, it would be interesting to examine if the stem PEP carboxylase can be activated under illumination, as is the case in leaves. 


\section{CONCLUSION}

As commonly observed in leaves, an increase in soil nitrogen supply had a positive impact on stem gas exchange and stem carbon refixation. The current-year stem seems to invest more $\mathrm{N}$ in $\mathrm{CO}_{2}$ refixation when more $\mathrm{N}$ is available, especially through PEP carboxylase whose activity increased. PEP carboxylase is probably involved in carbon refixation in stems and could concurrently supply $\mathrm{N}$ assimilation with carbon skeletons. Further investigations using ${ }^{13} \mathrm{C}$ as a tracer could be helpful to quantify the contribution of assimilated carbon to the various functions of the stem.

Acknowledgements: This research was financed by the "Programme National ACI/FNS ECCO, PNBC" (convention No. 0429 FNS). The ESE laboratory is supported by the University of ParisSud, the Centre National de la Recherche Scientifique (CNRS), and AgroParisTech. Two anonymous referees are thanked for constructive comments.

\section{REFERENCES}

Bauer G.A., Berntson G.M. and Bazzaz F.A., 2001. Regenerating temperate forests under elevated $\mathrm{CO}_{2}$ and nitrogen deposition: comparing biochemical and stomatal limitation of photosynthesis. New Phytol. 152: 249-266.

Berveiller D. and Damesin C., 2008. Carbon assimilation by tree stems: potential involvement of phosphoenolpyruvate carboxylase. TreesStruct. Func. 22: 149-157.

Berveiller D., Kierzkowski D. and Damesin C., 2007a. Interspecific variability of stem photosynthesis among tree species. Tree Physiol. 27: 53-61.

Berveiller D., Vidal J., Degrouard J., Ambard-Bretteville F., Jaillard D. and Damesin C., 2007b. Tree stem phosphoenolpyruvate carboxylase (PEPC): lack of biochemical and localization evidence for a $\mathrm{C}_{4}$-like photosynthesis system. New Phytol. 176: 775-781.

Bradford M.M., 1976. A rapid and sensitive method for the quantification of microgram quantities of protein utilizing the principe of proteindye binding. Anal. Biochem. 72: 248-254.

Cernusak L.A. and Marshall J.D., 2000. Photosynthetic refixation in branches of Western Pine. Funct. Ecol. 14: 300-311.

Damesin C., 2003. Respiration and photosynthesis characteristics of current-year stems of Fagus sylvatica: from the seasonal pattern to an annual balance. New Phytol. 158: 465-475.

Damesin C., Ceschia E., Le Goff N., Ottorini J.-M. and Dufrêne E., 2002. Stem and branch respiration of beech: from tree measurements to estimations at the stand level. New Phytol. 158: 159-172.

Evans J.R., 1989. Photosynthesis and nitrogen relationships in leaves of $\mathrm{C}_{3}$ plants. Oecologia 78: 9-19.

Field C. and Mooney H.A., The photosynthesis-nitrogen relationship in wild plants, 1986. In: Givnish T.J. (Ed.), On the economy of plant form and function, Cambridge University Press, Cambridge, pp. $25-55$.

Gessler A., Schneider S., Von Sengbusch D., Weber P., Hanemann U., Huber C., Rothe A., Kreutzer K. and Rennenberg H., 1998. Field and laboratory experiments on net uptake of nitrate and ammonium by the roots of spruce (Picea abies) and beech (Fagus sylvatica) trees. New Phytol. 138: 275-285.

Glass A.D.M. and Siddiqi M.Y., Nitrogen absorption by plant roots, 1995. In: Strivastava H.S. and Singh R.P. (Eds.), Nitrogen Nutrition in Higher Plants, Associated Publishing Co., New Delhi, pp. 21-56.
Gomez L. and Faurobert M., 2002. Contribution of vegetative storage proteins to seasonal nitrogen variations in the young shoots of peach trees (Prunus persica L. Batsch). J. Exp. Bot. 53: 2431-2439.

Gower S.T., Reich P.B. and Son Y., 1993. Canopy dynamics and aboveground production of five tree species with different leaf longevities. Tree Physiol. 12: 327-345.

Granier A., Ceschia E., Damesin C., Dufrene E., Epron D., Gross P., Lebaube S., Le Dantec V., Le Goff N., Lemoine D., Lucot E., Ottorini J.-M., Pontailler J.-Y. and Saugier B., 2000. The carbon balance of a young Beech forest. Funct. Ecol. 14: 312-325.

Hikosaka K., Hanba Y.T., Hirose T. and Terashima I., 1998. Photosynthetic nitrogen-use efficiency in leaves of woody and herbaceous species. Funct. Ecol. 12: 896-905.

Huppe H.C. and Turpin D.H., 1994. Integration of Carbon and Nitrogen Metabolism in Plant and Algal Cells. Annu. Rev. Plant Physiol. Plant Mol. Biol. 45: 577-607.

Kharouk V.I., Middleton E.M., Spencer S.L., Rock B.N. and Williams D.L., 1995. Aspen bark photosynthesis and its significance to remote sensing and carbon budget estimates in the boreal ecosystem. Water Air Soil Pollut. 82: 483-497.

Kreuzwieser J., Herschbach C., Stulen I., Wiersema P., Vaalburg W. and Rennenberg H., 1997. Interactions of $\mathrm{NH}_{4}^{+}$and L-glutamate with $\mathrm{NO}_{3}^{-}$transport processes of non-mycorrhizal Fagus sylvatica roots. J. Exp. Bot. 48: 1431-1438.

Lee R.B. and Drew M.C., 1989. Rapid, reversible inhibition of nitrate influx in barley by ammonium. J. Exp. Bot. 40: 741-752.

Li B., Zhang X.Q. and Chollet R., 1996. Phosphoenolpyruvate carboxylase kinase in tobacco leaves is activated by light in a similar but not identical way as in maize. Plant Physiol. 111: 497-505.

Makino A., Nakano H. and Mae T., 1994. Responses of Ribulose-1,5Bisphosphate Carboxylase, Cytochrome-F, and Sucrose synthesis enzymes in rice leaves to leaf Nitrogen and their relationships to photosynthesis. Plant Physiol. 105: 173-179.

Manetas Y., 2004. Probing corticular photosynthesis through in vivo chlorophyll fluorescence measurements: evidence that high internal $\mathrm{CO}_{2}$ levels suppress electron flow and increase the risk of photoinhibition. Physiol. Plant. 120: 509-517.

Martin F. and Plassard C., Assimilation de l'azote par les symbioses ectomycorhiziennes, 1997. In: Morot-Gaudry J.-F. (Ed.), Assimilation de l'azote des chez les plantes, INRA, Paris, pp. 179-193.

McCree K.J., An equation for the rate of respiration of white clover plants grown under controlled conditions, Proceedings of the technical meeting IBP, Centre for Agricultural Publishing and Documentation, Wageningen, Trebon (CSK), 1969, pp. 221-229.

Millard P., 1994. Measurements of the remobilization of nitrogen for spring leaf growth of trees under field conditions. Tree Physiol. 14: $1049-1054$.

Millard P. and Proe M.F., 1992. Storage and internal cycling of N in relation to seasonal growth of sitka spruce. Tree Physiol. 10: 33-43.

Pate J.S., 1973. Uptake, assimilation and transport of nitrogen compounds by plants. Soil Biology and Biochemistry 5: 109-119.

Pearson L.C. and Lawrence D.B., 1958. Photosynthesis in aspen bark. Am. J. Bot. 45: 383-327.

Pfanz H., Aschan G., Langenfeld-Heyser R., Wittmann C. and Loose M., 2002. Ecology and ecophysiology of tree stems: corticular and wood photosynthesis. Naturwissenschaften 89: 147-162.

Pilarski J., 1989. Photosynthesis in shoots and leaves of lilac (Syringae vulgaris L.). Bull. Pol. Acad. Sci. Biol. Sci. 37: 261-269.

Poorter H. and Evans J.R., 1998. Photosynthetic nitrogen-use efficiency of species that differ inherently in specific leaf area. Oecologia 116: 26-37. 
Rennenberg H., Schneider S. and Weber P., 1996. Analysis of uptake and allocation of nitrogen and sulphur compounds by trees in the field. J. Exp. Bot. 47: 1491-1498.

Ripullone F., Grassi G., Lauteri M. and Borghetti M., 2003. Photosynthesis-nitrogen relationships: interpretation of different patterns between Pseudotsuga menziesii and Populus x euroamericana in a mini-stand experiment. Tree Physiol. 23: 137-144.

Rowland L.J. and Arora R., 1997. Proteins related to endodormancy (rest) in woody perennials. Plant Sci. 126: 119-144.

Ryan M.G., 1991. Effects of climate on change on plant respiration. Ecol. Appl. 1: 157-167.

Sage R.F., Pearcy R.W. and Seemann J.R., 1987. The nitrogen use efficiency of C3 and C4 Plants: 3. Leaf nitrogen effects on the activity of carboxylating enzymes in Chenopodium album (L.) and Amaranthus retroflexus (L.). Plant Physiol. 85: 355-359.

Schaedle M. and Brayman A., 1986. Ribulose-1,5-bisphosphate carboxylase activity of Populus tremuloides Michx. bark tissues. Tree Physiol. 1: 53-56.

Stadler J., Gebauer G. and Schulze E.D., 1993. The influence of ammonium on nitrate uptake and assimilation in 2-year-old ash and oak trees - a tracer study with ${ }^{15} \mathrm{~N}$. Isotopenpraxis 29: 85-92.

Stepien V., Sauter J.J. and Martin F., 1994. Vegetative storage proteins in woody-plants. Plant Physiol. Biochem. 32: 185-192.
Tietz S. and Wild A., 1991. Investigations on the phosphoenolpyruvate carboxylase activity of spruce needles relative to the occurrence of novel forest decline. J. Plant Physiol. 137: 327-331.

Tischner R., 2000. Nitrate uptake and reduction in higher and lower plants. Plant Cell Environ. 23: 1005-1024.

Uedan K. and Sugiyama T., 1976. Purification and characterization of phosphoenolpyruvate carboxylase from maize leaves. Plant Physiol. 57: 906-910.

Volk R., Chaillou S., Mariotti A. and Morotgaudry J.F., 1992. Beneficial effects of concurrent ammonium and nitrate nutrition on the growth of Phaseolus vulgaris - a N15 study. Plant Physiol. Biochem. 30: 487-493.

Wiebe H.H., 1975. Photosynthesis in wood. Physiol Plant 332: 45-46.

Wittmann C., Aschan G. and Pfanz H., 2001. Leaf and twig photosynthesis of young beech (Fagus sylvatica) and aspen (Populus tremula) trees grown under different light regime. Basic Appl. Biol. 2: 145154.

Wittmann C. and Pfanz H., 2007. Temperature dependency of bark photosynthesis in beech (Fagus sylvatica L.) and birch (Betula pendula Roth.) trees. J. Exp. Bot. 58: 4293-4306.

Wittmann C., Pfanz H., Loreto F., Centritto M., Pietrini F. and Alessio G., 2006. Stem $\mathrm{CO}_{2}$ release under illumination: corticular photosynthesis, photorespiration or inhibition of mitochondrial respiration? Plant Cell Environ. 29: 1149-1158. 